ACta Universitatis Sapientiae

Agriculture And Environment, 5, (2013) 5-18

DOI: 10.2478 /ausae-2014-0001

\title{
Effects of cycocel priming on growth and early development of rapeseed under drought stress
}

Alireza POURMOHAMMAD

email: pourmohammad@ymail.com
Fariborz SHEKARI

email: fb_shekari@yahoo.com

\section{Veeda SOLTANIBAND}

email: soltani.agri@gmail.com

University of Maragheh, Faculty of Agriculture, Department of Agronomy and Plant Breeding,

Maragheh, Iran

\begin{abstract}
An experiment was concluded to evaluate the effects of priming on germination characteristics and establishment of rapeseed seedlings during three stages. In the first and second stages of experiment, the effects at three factors vis: cultivars (RVS, Hayola), waterdeficit stress (Control,-6 and -12 bar) and cycocel treatment (dry seeds, $300,600,900,1200$ and $1500 \mu \mathrm{M}$ ) on germination and seedling growth of plant were assayed. The results showed that priming had positive effects on germination percentage, germination rate index, germination index, and radicle length under water-deficit conditions. RVS had greater efficiency than other cultivars. The third section of experiment revealed that the priming of RVS seeds improved the stem, root and dry weight, total dry weight as well as leaf number and area of seedlings.
\end{abstract}

Keywords: germination, seedling growth and establishment, LAR, LWR

\section{Introduction}

Germination is the first stage of plant development, having crucial role in seedling emergence and establishment. Germination is greatly affected by environmental stimuli, especially temperature and soil humidity [3]. Since seedling establishment is a sensitive stage in crop growth and development with 
direct planting, uniformity and high emergence percentage have prominent effects on yield and production quality [30].

Rapeseed, an important oil-bearing crop, has been shown to be adapted in water-deficit conditions [1]. Owing to the prevalence of semi-dry growing locations in most parts of Iran, rapeseed may be a promising crop that meets the demands for edible oil $[1,12]$. Since the main production of rapeseed occurs under dry-land farming, plant responses to drought stress are worthy of great consideration [13]. Optimum seed germination and emergence potential under drought conditions provide the better establishment, and subsequently lead to yield increment [5].

Recently, huge attention has been paid to the enhancement of seed vigour for greater germination and seedling growth parameter under extreme environments [21]. Priming has been defined as a useful method for the improvement in seed germination and subsequent growth under stressful conditions [13]. Several studies have been demonstrated the prominent positive effects of priming on germination-related traits of several crop species $[22,23,28]$. In general, priming affects the hydration / dehydration ratio of seeds in favour of increased and hastened germination percentage and rate [8]. This in part promotes the seedling establishment and its later growth and development [17]. From biochemical and physiological point of view, priming goes to increases in antioxidant pool [14], the amount and translocation of soluble sugars [19] and protein biosynthesis [10]. Also, priming enhances the transcription and translocation of some genes [11] and affects membrane integrity [6]. CCC (Cycocel) is a widely employed growth retardant composed of a four-member oniumic group [2]. Scarisbrick et al. [25] noted that cycocel effects on plant growth and development were highly dependent on cultivar and species. Drought tolerance has been defined as the most common consequence of exogenous application of cycocel on most plant species [25].

In the present experiment, we aim to evaluate the effects of CCC on germination and early growth of several rapeseed cultivars under water-deficit conditions.

\section{Materials and methods}

This experiment was conducted in the Research Laboratory of the Agronomy and Plant Breeding Department at the University of Maragheh during autumn 2009. The treatments were two spring rapeseed cultivars (Hayola 401 and RVS), drought stress levels using sucrose (0, -6 and -12 bar) and cycocel 
concentrations $(0,300,600,900,1200$ and $1500 \mu \mathrm{M})$. Experimental design was factorial based on CRD with three replications. The seeds were surfacesterilized with $5 \%$ sodium hypochlorite. Cycocel treatments were applied on seeds for $24 \mathrm{hrs}$ at $10^{\circ} \mathrm{C}$. Then seeds were rinsed with sterile distilled water and were left to dry till they reached their primary weight. In the first step, 50 seeds placed in a Petri dish between filter papers were transferred into incubator at $20^{\circ} \mathrm{C}$ for 7 days. The seeds were surveyed daily and FGP (Final Germination Percentage), CVG (Coefficient for Velocity of Germination), GRI (Germination Rate Index) and GI (Germination Index) were measured [15]. In the second series of experiments, the primed seeds wrapped in filter papers were transferred into incubator at $20^{\circ} \mathrm{C}$ for 7 days. The drought stress treatment was the same as the first experiments. The recorded traits beyond seven days were radicle length, plumule length, plumule dry weight, radicle dry weight and dry seed weight. In the third experiment, primed and control seeds (RVS cultivar) were planted in the pots at a depth of $15 \mathrm{~mm}$ and maintained at $20 \pm 2^{\circ} \mathrm{C}$ and 16:8 photoperiod. Experimental design was RCB with 4 replications. Drought stress levels were measured using control plants with $100 \%$ water availability and 30, 50 and $70 \%$ of available water computed by:

$$
\begin{aligned}
& \mathrm{L}=\left(1-\mathrm{PAW}_{\mathrm{t}} / \mathrm{AWC}\right) \times 100 \\
& \mathrm{PAW}_{\mathrm{t}}=\mathrm{SMC}-\mathrm{WP} \\
& \mathrm{AWC}=\mathrm{FC}-\mathrm{WP},
\end{aligned}
$$

where $\mathrm{PAW}_{\mathrm{t}}$ is plant available water in defined time (based on a 24-h period), AWC is available water content between wilting point (WP) and field capacity (FC), and SMC is soil moisture content in defined time (based on a 24-h period). Wilting point was quantified by pressure-plate system, and the treatments were applied based on weight percentage. At the end of the 40-day period, emerged seeds percentage, stem dry weight, leaf dry weight, total dry weight, leaf number, leaf area ratio (LAR), stem/root ratio (S/R), and leaf weight ratio were measured. Data were analysed with SAS and MSTATC software, and graphs were drawn in Excel programme. Mean comparisons were carried out by Duncan's multiple range test at $P<0.01$.

\section{Results and discussions}

In the first stage of the experiment, CCC improved all growth-related traits. Based on the results of cycocel treatment, stress levels and interaction effects of stress and cultivar were significant on FGP $(P \leq 0.01)$. Mean comparison 
revealed that cycocel application had significant effect on FGP. However, there was no significant difference between cycocel levels (Table 1).

Table 1: The effects of cycocel amounts on rapeseed germination characteristics in the first experiment

\begin{tabular}{cccc}
\hline & $\begin{array}{c}\text { Final } \\
\text { Germination } \\
\text { Percentage } \\
(\text { FGP })\end{array}$ & $\begin{array}{c}\text { Coefficient for } \\
\text { Velocity of } \\
\text { Germination } \\
\text { (CVG) }\end{array}$ & $\begin{array}{c}\text { Germination } \\
\text { Index (GI) }\end{array}$ \\
\hline $0 \mu \mathrm{M}$ & $70.9 \mathrm{~b}$ & $0.35 \mathrm{~b}$ & $73.6 \mathrm{~b}$ \\
$300 \mu \mathrm{M}$ & $73.6 \mathrm{ab}$ & $0.44 \mathrm{a}$ & $84.8 \mathrm{a}$ \\
$600 \mu \mathrm{M}$ & $79.7 \mathrm{a}$ & $0.48 \mathrm{a}$ & $90.0 \mathrm{a}$ \\
$900 \mu \mathrm{M}$ & $80.7 \mathrm{a}$ & $0.45 \mathrm{a}$ & $87.8 \mathrm{a}$ \\
$1200 \mu \mathrm{M}$ & $80.3 \mathrm{a}$ & $0.42 \mathrm{a}$ & $92.7 \mathrm{a}$ \\
$1500 \mu \mathrm{M}$ & $81.1 \mathrm{a}$ & $0.45 \mathrm{a}$ & $91.7 \mathrm{a}$ \\
\hline Probability Level & $* *$ & $* *$ & $* *$ \\
\hline
\end{tabular}

** Means significant at $\mathrm{P} \leq 0.01$ based on Duncan's multiple range test

Under normal (non-stress) conditions, FGP values were non-significant for all the studied varieties; however, with severe stress, RVS demonstrated the higher FGP values compared to other cultivars (Table 3). CVG values in case of all pretreated seeds were higher than dry seeds (Table 2).

Table 2: The effects of drought stress levels on rapeseed germination and seedling characteristics in the first and second experiment, respectively

\begin{tabular}{ccccc}
\hline & $\begin{array}{c}\text { Coefficient for } \\
\text { Velocity of } \\
\text { Germination }\end{array}$ & $\begin{array}{c}\text { Plumule dry } \\
\text { weight } \\
(\mathrm{g})\end{array}$ & $\begin{array}{c}\text { Radicle } \\
\text { dry weight } \\
(\mathrm{g})\end{array}$ & $\begin{array}{c}\text { Plumule } \\
\text { length } \\
(\mathrm{cm})\end{array}$ \\
\hline 0 bar & $0.68 \mathrm{a}$ & $0.0130 \mathrm{a}$ & $0.008 \mathrm{a}$ & $3.10 \mathrm{a}$ \\
-6 bar & $0.40 \mathrm{~b}$ & $0.0120 \mathrm{a}$ & $0.004 \mathrm{~b}$ & $0.89 \mathrm{~b}$ \\
$-12 \mathrm{bar}$ & $0.22 \mathrm{c}$ & $0.0001 \mathrm{~b}$ & $0.001 \mathrm{c}$ & $0.04 \mathrm{c}$ \\
\hline Probability Level & $* *$ & $* *$ & $* *$ & \\
\hline
\end{tabular}

** Means significant at $\mathrm{P} \leq 0.01$ based on Duncan's multiple range test 
Table 3: The interaction of drought stress levels and rapeseed cultivars on germination and seedling characteristics in the first and second experiment

\begin{tabular}{|c|c|c|c|c|}
\hline & $\begin{array}{c}\text { Final } \\
\text { Germination } \\
\text { Percentage } \\
(\text { FGP })\end{array}$ & $\begin{array}{c}\text { Germination } \\
\text { Rate } \\
\text { Index } \\
(\mathrm{GI})\end{array}$ & $\begin{array}{l}\text { Germination } \\
\text { Index (GI) }\end{array}$ & $\begin{array}{l}\text { Seed dry } \\
\text { weight }\end{array}$ \\
\hline $\mathrm{RVS} \times 0$ bar & $90.83 \mathrm{a}$ & $71.52 \mathrm{a}$ & $119.3 \mathrm{a}$ & $0.1556 \mathrm{e}$ \\
\hline RVS $\times-6$ bar & $93.61 \mathrm{a}$ & $74.83 \mathrm{a}$ & $122.1 \mathrm{a}$ & $0.2333 \mathrm{~d}$ \\
\hline $\mathrm{RVS} \times-12$ bar & $86.94 \mathrm{a}$ & $37.38 \mathrm{c}$ & $95.8 \mathrm{c}$ & $0.8389 \mathrm{a}$ \\
\hline Hayola $401 \times 0$ bar & $93.33 \mathrm{a}$ & $44.27 \mathrm{~b}$ & $108.2 \mathrm{~b}$ & $0.3889 \mathrm{c}$ \\
\hline Hayola $401 \times-6$ bar & $31.94 \mathrm{c}$ & $6.690 \mathrm{e}$ & $21.5 \mathrm{e}$ & $0.4944 \mathrm{~b}$ \\
\hline Hayola $401 \times-12$ bar & $68.89 \mathrm{~b}$ & $19.10 \mathrm{~d}$ & $53.6 \mathrm{~d}$ & $0.0085 \mathrm{a}$ \\
\hline Probability Level & $* *$ & $* *$ & $* *$ & $* *$ \\
\hline
\end{tabular}

** Means significant at $\mathrm{P} \leq 0.01$ based on Duncan's multiple range test

In contrast, severe drought stress led to reduced amounts of CVG (Table 1). Homogenous and increased germination percentage behind cycocel pretreatment has been demonstrated earlier [4]. For instance, the priming of corn seeds with polyethylene glycol 4000, urea and water had promising effects on germination rate and percentage [21]. These results are similar to the findings of Shad et al. [26] in soybean. Also, Shekari [27] reported that salt and some other ionic solution pretreatments enhanced the germination-related traits in rapeseed. Emergence of pepper plants was also positively influenced by CCC pretreatment in Demir \& Ellis [9] research. Increase in respiration potential and ATP generation, as well as enhanced transcription levels and protein synthesis have been reported as the main effects of the seeds pretreatment with priming agents [9]. Rashid et al. [24] reported that hydropriming led to early germination, higher establishment and increased yield in some crops under normal and stressful growing conditions. Early emergence of seedlings in regions with limited growth period is worthy of great attention. In other words, early and hastened leaf area expansion goes to the optimum light perception and subsequently greater growth potential compared with weeds. These all finally lead to increased dry matter accumulation and yield [1].

The results also showed that the main and interaction effects of cyco$\mathrm{cel}^{*}$ stress and stress*cultivar were significant. Cycocel treatment with nonstress conditions had higher values for most traits than dry seeds (Table 4). With the increase in water-deficit levels and at -6 bars, primed seeds treated with $600 \mu \mathrm{M}$ cycocel had higher GRI values than control seeds, but the difference within cycocel levels was not significant. 


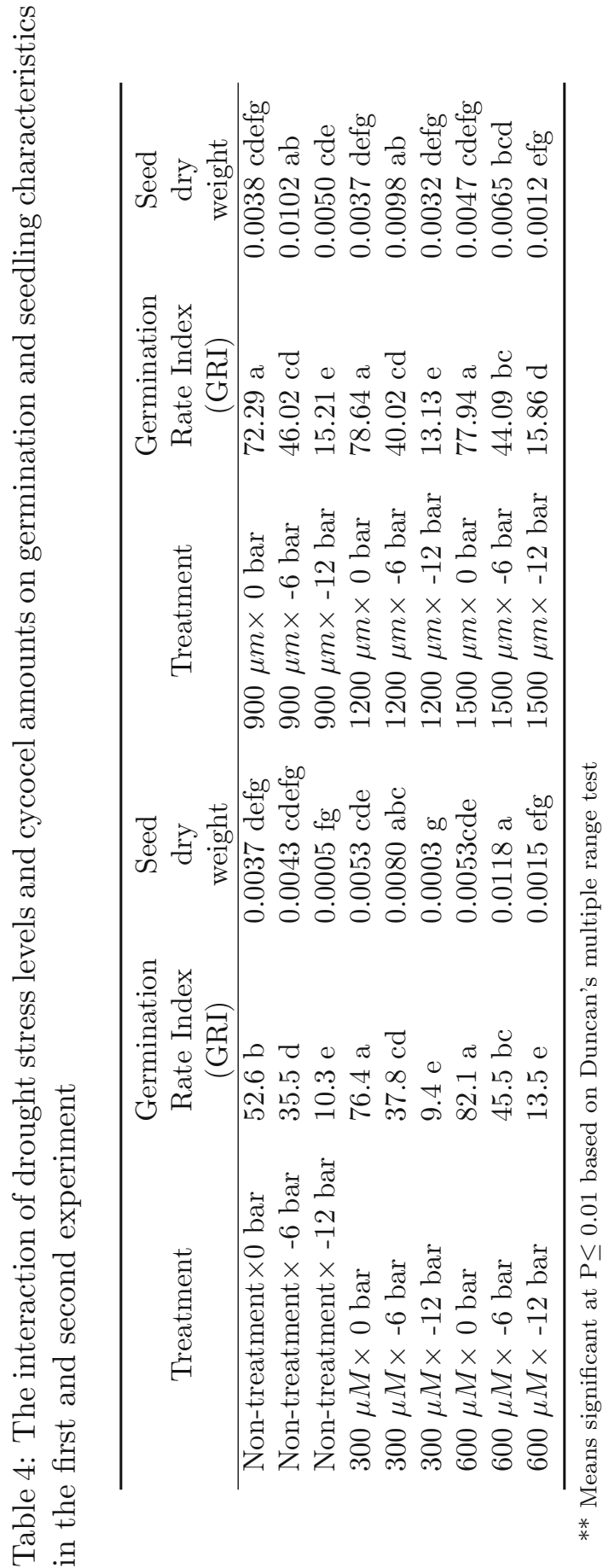


Under severe stress conditions (-12 bar), there was no significant difference between primed seeds and control ones (Table 4). Mean comparison revealed that the studied verities had no significant difference under non-stress conditions, but under stress conditions - under both mild and intense stress levels-, 'RVS' had the higher GRI amount compared to other cultivars (Table 3). The main and interaction effects of stress* cultivar were significant $(P \leq 0.01)$ on GRI. GRI ratios for primed seeds were higher than those for non-primed seeds, whereas dry seeds had the lowest GRI values (Table 1). Under normal conditions, there was no difference among cultivars regarding GRI, but under intense stress, RVS was more promising than other cultivars, mainly due to its greater efficiency for early growth and development, especially under stressful conditions. Moradi Dezfuli et al. [21] reported the same results. Shekari et al. [27] also reported that the different priming solutions also increased the GRI values for rapeseed.

In the second part of the experiment, cycocel pretreatment increased the radicle length. In this case, the main and the interaction effects of pretreatment*stress levels as well as the interaction of pretreatment stress levels*cultivar were significant on radicle length (Table 5). Mean comparisons revealed that, under non-stress conditions, primed seeds disposed of higher radicle length compared to dry seeds. With mild stress application, primed seeds in both varieties had the highest radical length in contrast with nontreated seeds. In other words, dry seeds had an especially low efficiency for radicle growth and subsequent development (Table 5).

The results from the second section of the experiment revealed that cycocel pretreatment positively influenced the radicle length (Table 5). The interaction effects were significant for the treatments. Considering this, and under non- stress environment, pretreated varieties had the longer radicles compared to control ones. The same trend was observed under mild stressful conditions. In contrast, with severe stress, there were no significant differences between treatments (Table 5). In germination studies, radicle length assay has been defined as a reliable criterion for the prediction of subsequent seedling growth, and as a logical consequence it influences plant growth and development during early growth encountered with drought environment [1]. Following the pretreatment with different solutions [16, 21], the same results have been reported with diverse plant species for radicle length. At the same time, Subedi \& Ma [29] noted that GA3 pretreatment not only had no ameliorative effect on radicle length, but in most treatments it also reduced the radicle length in corn. Cycocel pretreatment had no significant influence on plumule length (table not shown). 


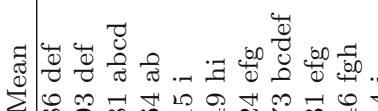

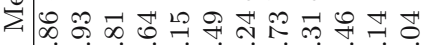

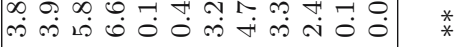

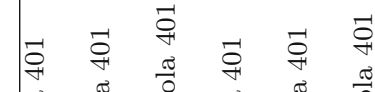

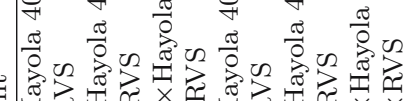

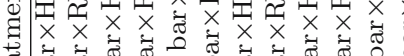

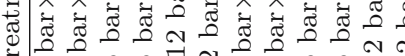

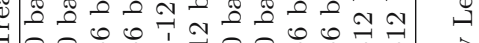

$\dot{x} \dot{x} \dot{x} \dot{x} \times \vec{x} \dot{x} \dot{x} \dot{x} \dot{x} \dot{x} \dot{x}$

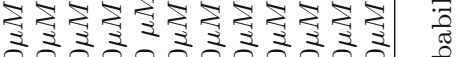

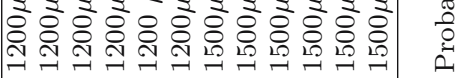

శี

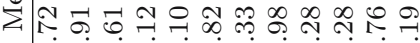

o

荫

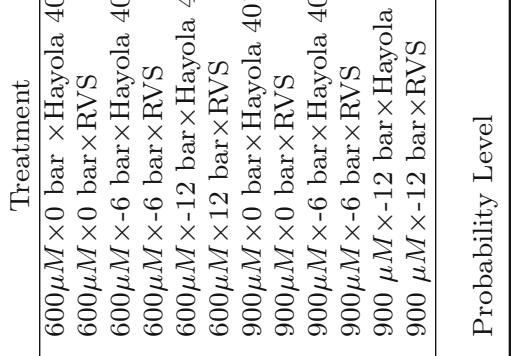

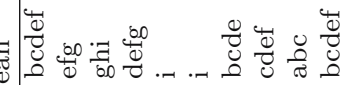

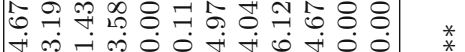

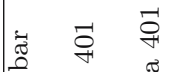

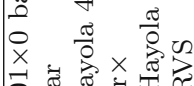

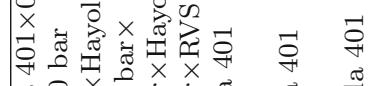

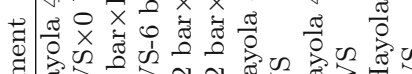

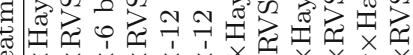

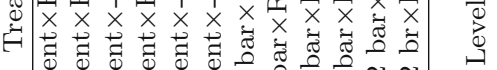

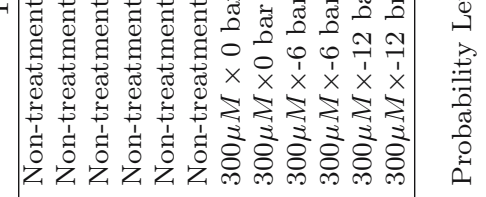


Any increase in the stress intensity led to reduced plumule length. The same results were observed in the case of plumule and radicle dry weight (table not shown). Several previous studies reported that using hormonal and non-hormonal solutions for pretreatment of seeds may have divergent effects on the aforementioned traits $[27,29]$. Thus, the effects may be promotive, preventative and, in some cases, natural. These variant effects may be in main part due to the agent type, its amount and the plant species. For seed dry weight, interactions of pretreatment*stress level and stress level*cultivar were significant $(P \leq 0.01)$. Accordingly, the highest data for seed dry weight was recorded in the third level of stress (Table 4). For the stress and cultivar interaction, the results showed that under severe stress conditions, the greatest seed dry weight belonged to "Hayola 401". However, there was no meaningful difference between varieties considering the above trait. This all means that in RVS cultivar seed storage compounds may have higher mobility during the germination process and the later potential enhances the seeds' germination capabilities, and subsequently increases the seedling establishment under fieldgrown conditions [27].

In the third section of the experiment, total dry weight (sum of aerial and underground parts) produced the greatest data with $100 \%$ available moisture and $900 \mu \mathrm{M}$ cycocel (table not shown). The same trend was detectable with any increase in stress intensity. Regarding this trait, $600 \mu \mathrm{M}$ cycocel treatment possessed the next rank (table not shown). With all stress levels, dry seeds (control) had the least amount for seed dry weight. Like with ours, Shekari et al. [27] reported that salicylic acid treatment increased the total dry weight of Borago officinalis L. seedlings. Kaydan et al. [18] also reported that under salinity stress conditions, hormonal pretreatment enhanced the seedling dry weight of wheat. The same results were recorded for aerial parts (leaves and stem) dry weight (table not shown). Root dry weight followed the same pattern as well, so that, the application of 600 and $900 \mu \mathrm{M}$ cycocel had the most promising effect on this trait (table not shown). Simultaneously, with all stress levels, any shortage in available water content led to the reduced root growth. Under severe stress, the prominent decrease in root growth was evidenced. This is a classical viewpoint that, under severe drought stress, photoassimilate partitioning towards the roots adversely affected, and this in turn goes to reduced root growth rate and diminished underground dry weight [27]. Shekari et al. [27] demonstrated that Brassica rapa seeds pretreated with different ionic and non-ionic solutions had increased shoot and root dry weight. Pretreated seeds gained the highest data for leaf number and area compared with control non-treated seeds. The $100 \mu \mathrm{M}$ cycocel treatment produced the 
near-maximum data for leaf number and area. Our findings are well in conformity with the reports of Martin-Mex [20] and Shekari et al.[27]. Aerial to underground parts ratio $(\mathrm{S} / \mathrm{R})$ was affected by the treatments, and with all pretreated seeds the ratio was lower than with control ones. The data for $\mathrm{S} / \mathrm{R}$ was aligned with the previous sections of the present experiment. This means that the pretreatments mainly affected the underground parts, and hence the $\mathrm{S} / \mathrm{R}$ ratio.

Contrarily, leaf area ratio (LAR) and leaf weight ratio (LWR) for pretreated seeds were lower than for control seeds mainly due to elevated total dry weight per leaf area and leaf dry weight (table not shown). This is more highlighted, considering the improved underground parts growth and dry matter accumulation, especially under water-deficit conditions. As previously understood, water deficiency affects the growth potential of plants in favour of the underground parts [7]. The results from the present experiment verify the great effects of cycocel on plant growth and development. Furthermore, the findings emphasize the interaction effects of drought stress, varieties and their crosstalk with hormonal pretreatment. Overall, cycocel pretreatment has the potential to affect the pre-germination stages of seeds in favour of improved early growth and development of the seedlings, particularly under water-deficit stressful conditions. However, its effect is partly species dependent. Finally, in the present experiment, cycocel at $600-1200 \mu \mathrm{M}$ had promising effect on the seeds' germination-related traits, and RVS had also more potential for stress escape with cycocel pretreatment. The other main advantage of RVS was its strong response to severe stress levels.

\section{Conclusion}

However, the positive effects of CCC coping with drought stress have been frequently verified, but - due to a vast range of feedbacks - there is a great need for further studying its effects and application method on plant growth and development under harsh conditions. In the present experiment, CCC treatment potentiated to enhance the germination-related traits under both normal and stressful conditions. Moreover, varieties had diverse responses to CCC application. Considering seed vigour characteristics, CCC was able to increase radicle length and reservoir mobilization, but, under intense stress, the ameliorative effects of CCC were decreased. Seed priming with CCC significantly affected the plant growth characteristics, so that, total dry weight and photosynthesis potential of plants were amended by the treatments mainly 
due to the increased leaf number and area as well as the overall plant growth improvement.

\section{References}

[1] Alyari, H., Shekari, F. and Shekari, F. (2000), Oil seed crops: Agronomy and Physiology. Amidi Publication, Tabriz (in Persian).

[2] Amarjit, B. (2000), Plant growth regulators in Agriculture and Horticulture: Their role and commercial uses. Food Products Research, New York.

[3] Anda, A. and Pinter, L. (1994), Sorghum germination and development as influenced by soil temperature and water contact. Agronomy Journal 86, pp. 621-624.

[4] Ashraf, M. and Foolad, M. R. (2005), Pre-sowing seed treatment - a shotgun approach to improve germination growth and crop yield under saline and non-saline conditions. Advances in Agronomy 88, pp. 223-271.

[5] Baalbaki, R. Z., Zurayk , R. A., Blelk, M. M. and Tahouk, S. N. (1999), Germination and seedling development of drought tolerant and susceptible wheat under moisture stress. Seed Science and Technology 27, pp. 291-302.

[6] Bradford, K. J., Steinert, J. J. and Trawatha, S. E. (1990), Seed priming influence on germination and emergence of pepper seed lots. Crop Science 30, pp. 718-721.

[7] Carrow, R. N. (1996), Drought resistance aspect of turf grasses in the South-East: root-shoot responses. Crop Science 36, pp. 687-694.

[8] De Villiers, A. J., Van Rooyrn, M. W., Theron, G. K., Van Deventer, H. A. (1994), Germination of three namaqualand pioneer species, as influenced by salinity, temperature and light. Seed Science and Technology 22 , pp. 427-433.

[9] Demir, I. and Ellis, R. (1994), The effects of priming on germination and longevity of harvest pepper seed lots. Turkish Journal of Agriculture and Forestry 18, pp. 213-217. 
[10] Fujikura, Y. and Karssen, C. M. (1992), Effects of controlled deterioration and osmopriming on protein synthesis of cauliflower seeds during early germination. Seed Science Research 2, pp. 23-31.

[11] Garcia, F. C., Jimenz, L. F. and Vazquez-Ramos, J. M. (1995), Biochemical and cytological studies on osmoprimed maize seeds. Seed Science Research 5, pp. 12-23.

[12] Ghassemi-Golezani, K., Khomari, S., Valizadeh, M. and Alyari, H. (2008), Effect of seed vigor and the duration of cold acclimation on freezing tolerance of winter oilseed rape. Seed Science and Technology 36, pp. $767-775$.

[13] Harris, D., Joshi, A., Khan, P. A., Gothkar, P. and Sodhi, P. S. (1999), On-farm seed priming in semi-arid agriculture: Development and evaluation in maize, rice and chickpea in India using participatory methods. Experimental Agriculture 35, pp. 15-29.

[14] Hus, J. L. and Song, J. M. (1997), Antioxidant role of glutathione associated with accelerated aging and hydration of triploid watermelon seeds. Physiologia Plantarum 100, pp. 967-974.

[15] Jones, K. and Sanders, D. (1987), The influence of soaking pepper seed in water or potassium salt solutions on germination at three temperatures. Journal of Seed Technology 11, pp. 97-102.

[16] Kara, I. G. N. (1998), Response of wheat and barley during germination to seed osmopriming at different water potential. J. Agron. Crop Science 181, pp. 229-235.

[17] Kaur, S. A., Gupta, K., Kaur, N. (2006), Effect of hydro- and osmopriming of chickpea (Cicerarietinum L.) seeds on enzymes of sucrose and nitrogen metabolism in nodules. Plant Growth Regulation 49, pp. $177-182$.

[18] Kaydan, D., Yagmur, M., Okut, N. (2007), Effect of salicylic acid on the growth and some physiological characters in salt stressed wheat (Triticum aestivum L.). Tarim Bilimleri Dergisi 13, pp. 114-119.

[19] Khan, A. A., Tao, K. L., Knyple, J. S., Brokowska, B. and Powell, L. E. (1978), Osmotic conditioning of seeds: Physiological and biochemical changes. Acta Horticulturae 83, pp. 267-278. 
[20] Martin-Mex, R., Villanueva-Couoh, E., Herra-Campos, T. (2005), Positive effect of salicylates on the flowering of African Violet. Scientia Horticulturae 103, pp. 499-502.

[21] Moradi Dezfuli, P., Sharif-zadeh, P., Janmohammadi, M. (2008), Influence of priming techniques on seed germination behavior of maize inbred lines (Zea mays L.). Journal of Agricultural and Biological Science 3, pp. $23-25$.

[22] Murungu, F. S., Nyamugafata, P., Chiduza, C., Clark, L. J., Whalley, W. R. (2003), Effects of seed priming aggregate size and soil matric potential on emergence of cotton (Gossypium hirsutum L.) and maize (Zea mays L.). Soil and Tillage Research 74, pp. 161-168.

[23] Omidi, H., Sorosh Zadeh, A., Salehi, A., Ghezli, F. D. (2005), Evaluation osmo-priming pre-soaking on rapeseed seed germination. Agricultural Science Technology 19, pp. 125-136.

[24] Rashid, P., Aollington, A., Harris, D., Khan, K. (2005), On-farm seed priming for barely on normal, saline and saline-sodic soils in North West Frontier Province, Pakistan. European Journal of Agronomy 24, pp. 276281.

[25] Scarisbrick, D. H., Daniels, R. W., Noorrawi, A. B. (1982), The effect of chlormequat on the yield components of oil-seed rape (Brassica napus L.). Journal of Agricultural and Biological Science 99, pp. 453-455.

[26] Shad, K. K., John, G. M., Leigh, W. M. (2001), Germination of soybean seed primed in aerated solution of polyethylene glycol 8000. Journal of Agricultural and Biological Science 1, pp. 105-107.

[27] Shekari, F., Baljani, R., Saba, J., Afsahi, V. and Shekari, F. (2009), The effect of salicylic acid on growth characteristics of Borage (Borago officinalis L.). New Agricultural Sciences (in Persian) 6, pp. 47-53.

[28] Shekari, F., Javanshir, A., Shakiba, M. R., Moghaddam, M. and Alyari, H. (2000), Enhancement of canola seed germination and seedling emergence in low water potentials by priming. Turkish Journal of Field Crops 5, pp. 54-60. 
[29] Subedi, K. D., and Ma, B. L. (2005), Seed priming does not improve corn yield in a Humid temperate environment. Agronomy Journal 97, pp. 211-218.

[30] Thakur, A., Thakur, P. S. and Bhardway, A. (1997), Influence of seed osmoconditioning on germination potential and seedling performance of bell pepper. Seed Science Research 25, pp. 25-30. 